NBER WORKING PAPER SERIES

\title{
AN ASSESSMENT OF THE ENERGY-EFFICIENCY GAP AND ITS IMPLICATIONS FOR CLIMATE-CHANGE POLICY
}

Todd D. Gerarden

Richard G. Newell

Robert N. Stavins

Robert C. Stowe

Working Paper 20905

http://www.nber.org/papers/w20905

\author{
NATIONAL BUREAU OF ECONOMIC RESEARCH \\ 1050 Massachusetts Avenue \\ Cambridge, MA 02138 \\ January 2015
}

We are grateful to Marika Tatsutani for extensive editorial assistance. This paper draws in part on a workshop held at Harvard, October 24-25, 2013, "Evaluating the Energy Efficiency Gap," co-sponsored by the Duke University Energy Initiative and the Harvard Environmental Economics Program. We thank the participants for the insights they provided on the questions addressed at the workshop and in this paper. We gratefully acknowledge generous financial support from the Enel Foundation for the preparation of this paper and its presentation at the Twentieth Conference of the Parties of the United Nations Framework Convention on Climate Change - and the Alfred P. Sloan Foundation for a larger project on the energy-efficiency gap. The authors, however, are fully responsible for any errors and all opinions expressed in this paper. The views expressed herein are those of the authors and do not necessarily reflect the views of the National Bureau of Economic Research.

NBER working papers are circulated for discussion and comment purposes. They have not been peerreviewed or been subject to the review by the NBER Board of Directors that accompanies official NBER publications.

(C) 2015 by Todd D. Gerarden, Richard G. Newell, Robert N. Stavins, and Robert C. Stowe. All rights reserved. Short sections of text, not to exceed two paragraphs, may be quoted without explicit permission provided that full credit, including (C) notice, is given to the source. 
An Assessment of the Energy-Efficiency Gap and its Implications for Climate-Change Policy Todd D. Gerarden, Richard G. Newell, Robert N. Stavins, and Robert C. Stowe NBER Working Paper No. 20905

January 2015

JEL No. Q4,Q48

\begin{abstract}
Improving end-use energy efficiency - that is, the energy-efficiency of individuals, households, and firms as they consume energy - is often cited as an important element in efforts to reduce greenhouse-gas (GHG) emissions. Arguments for improving energy efficiency usually rely on the idea that energy-efficient technologies will save end users money over time and thereby provide low-cost or no-cost options for reducing GHG emissions. However, some research suggests that energy-efficient technologies appear not to be adopted by consumers and businesses to the degree that would seem justified, even on a purely financial basis. We review in this paper the evidence for a range of explanations for this apparent "energy-efficiency gap." We find most explanations are grounded in sound economic theory, but the strength of empirical support for these explanations varies widely. Retrospective program evaluations\suggest the cost of GHG abatement varies considerably across different energy-efficiency investmentsland can diverge substantially from the predictions of prospective models. Findings from research onlthe energy-efficiency gap could help policy makers generate social and private benefits from accelerating the diffusion of energy-efficient technologies - including reduction of GHG emissions.
\end{abstract}

Todd D. Gerarden

Harvard University

gerarden@fas.harvard.edu

Richard G. Newell

Nicholas School of the Environment

Duke University

Box 90227

Durham, NC 27708

and NBER

richard.newell@duke.edu

\author{
Robert N. Stavins \\ JFK School of Government \\ Harvard University \\ 79 JFK Street \\ Cambridge, MA 02138 \\ and NBER \\ robert_stavins@hks.harvard.edu \\ Robert C. Stowe \\ Kennedy School of Government \\ Harvard University \\ 79 JFK Street \\ Cambridge, MA 02138 \\ robert_stowe@harvard.edu
}




\title{
AN ASSESSMENT OF THE ENERGY-EFFICIENCY GAP AND ITS IMPLICATIONS FOR CLIMATE-CHANGE POLICY
}

\author{
Todd D. Gerarden, Richard G. Newell, Robert N. Stavins, Robert C. Stowe ${ }^{1}$
}

\section{INTRODUCTION}

Improving end-use energy efficiency — that is, the energy-efficiency of individuals, households, and firms as they consume energy - is often cited as an important element in efforts to reduce greenhousegas (GHG) emissions. Arguments for improving energy efficiency usually rely on the idea that energyefficient technologies will save end users money over time and thereby provide low-cost or no-cost options for reducing GHG emissions. Such an approach to mitigating GHG emissions is likely to be more politically feasible in countries whose governments may have concerns with public action to address climate change, such as financial incentives or requirements that place an explicit or implicit (shadow) price on carbon.

The most ambitious exercise in integrated assessment modeling to address the potential impact of improved energy efficiency on GHG emissions was that of the Energy Modeling Forum in 2010. Among other conclusions, the modeling team concluded that "...market penetration of energyefficiency improvements appears to be much more complicated than assuming that consumers select the least-cost strategy among a set of technology options." (Huntington and Smith 2011, 3) This conclusion is representative of a larger body of insight that suggests that while energy-efficient technologies offer considerable promise for reducing the financial costs and environmental damages

1 Gerarden is a Ph.D. student in Public Policy at Harvard University; Newell is the Gendell Professor of Energy and Environmental Economics at the Nicholas School of the Environment, Duke University, Research Associate of the National Bureau of Economic Research, and University Fellow of Resources for the Future; Stavins is the Albert Pratt Professor of Business and Government at the Harvard Kennedy School, Research Associate of the National Bureau of Economic Research, and University Fellow of Resources for the Future; and Stowe is the Executive Director of the Harvard Environmental Economics Program. We are grateful to Marika Tatsutani for extensive editorial assistance. This paper draws in part on a workshop held at Harvard, October 24-25, 2013, "Evaluating the Energy Efficiency Gap," co-sponsored by the Duke University Energy Initiative and the Harvard Environmental Economics Program. We thank the participants for the insights they provided on the questions addressed at the workshop and in this paper. We gratefully acknowledge generous financial support from the Enel Foundation for the preparation of this paper and its presentation at the Twentieth Conference of the Parties of the United Nations Framework Convention on Climate Change—and the Alfred P. Sloan Foundation for a larger project on the energy-efficiency gap. The authors, however, are fully responsible for any errors and all opinions expressed in this paper. 
associated with energy use-including those related to climate change-these technologies appear not to be adopted by consumers and businesses to the degree that would seem justified, even on a purely financial basis.

We review in this paper the evidence for a range of explanations for this apparent "energy-efficiency gap," finding relatively strong empirical support for some explanations and mixed or weak evidence for others. Policy makers are interested in better understanding the energy-efficiency gap, given the social and private benefits that could flow from accelerating the diffusion of energy-efficient technologiesincluding reduction of GHG emissions. ${ }^{2}$ With an eye to informing future efforts to craft effective public policy in this arena, we also identify priorities for further research.

\section{THE ENERGY-EFFICIENCY “GAP”}

Global energy consumption is on a path to grow 30-50 percent over the next 25 years. In many countries, this will result in higher energy prices and increased local air pollution and GHG emissions. Energy-efficient technologies could do much to slow the rate of growth in global energy consumption and reduce associated costs and environmental impacts. Moreover, engineering studies suggest that many of these technologies offer an attractive rate of return on investment, in the sense that they would pay for themselves in energy-cost savings over a relatively short period of time.

Yet it has long been observed that households and firms consistently "under-invest" in energy-efficient technologies - at least relative to the predictions of many engineering and economic models. At the level of individual decision-makers, this under-investment suggests the following questions: Why do consumers and businesses fail to adopt technologies that appear to be justified on the basis of their own (private) financial net benefits? At the level of society as a whole, why do efficient technologies appear to diffuse at a rate that is suboptimal relative to the social benefits they may offer (including climate-change mitigation)?

An extensive literature exists that attempts to explain this apparent energy-efficiency gap. The explanations that have received the most attention fall into three broad categories: (1) market failures, (2) behavioral effects, and (3) modeling flaws. Determining the validity of specific explanations within each of these categories — and assessing the degree to which each contributes to the energy-efficiency would pay off for adopters are nevertheless not adopted. This basic definition relates to the issue of private optimality. We define the "energy efficiency gap" as the apparent reality that some energy-efficiency technologies that would be socially efficient are not adopted. This broader concept relates to social optimality. In this brief, we use "energy efficiency gap" to refer to issues of private optimality and use no separate term for social benefits or costs. 
gap-are crucial steps in crafting effective public policy responses and in understanding the likely net benefits of such policies, including reduction in GHG emissions.

To organize our inquiry, we begin by "decomposing" the decision to invest (or not) in an energyefficiency improvement into its fundamental elements. Assuming that most businesses and households are interested in minimizing cost, these fundamental decision elements include the cost of purchasing and operating the technology in question (where operating costs are determined by the price of energy and usage levels), and the discount rate and time horizon that the decision maker applies to the initial investment. This decomposition generates four questions that are useful for thinking about potential causes of, and policy remedies for, the efficiency gap: 1) Are product offerings and pricing economically efficient? 2) Are energy operating costs inefficiently priced and/or understood? 3) Are product choices cost-minimizing in present value terms? 4) Do other costs inhibit more energy-efficient decisions? We summarize here the research relevant to each question and offer suggestions for future research.

\section{1) Are the energy-efficiency of products and the associated pricing of these products on the market, economically efficient?}

One set of possible explanations for the energy-efficiency gap centers on reasons why the number, diversity, and price of higher-efficiency products available to consumers could be fewer than optimal. For example, firms may not offer such products if they do not expect to recoup the fixed costs of developing them, or if they expect the introduction of more efficient models-and their efforts to market them-to cause shifts in consumer demand that will adversely affect sales of other products they offer and/or benefit competitors. Firms with a monopoly over certain markets or technologies, or firms with significant market power, may simply set the price of energy-efficient products above the socially efficient price. In addition, firms might under-invest in the research and development needed to bring more efficient products to market, because of so-called "spillovers" — referring to firms not being able to appropriate all of the knowledge and productivity gains from R\&D investments and from learning-by-doing to develop new products. (Instead, some of these benefits "spill over" to other firms.) Finally, consumers may not demand energy-efficient products simply because they lack information about these products.

Broadly speaking, a tension exists between optimal innovation and product offerings, on the one hand, and optimal adoption of energy-efficient products, on the other hand. This is because firms have to charge higher prices to recoup the fixed costs they incur to generate energy-efficiency improvements in products, but higher prices tend to discourage adoption. Optimal policy would seek to balance these two forces to encourage both innovation and adoption of energy-efficient products (Kamien and Schwartz 1982). 
This tension is generic in the sense that the factors that could lead to suboptimal product offeringswhether they involve market failures, imperfect information, spillovers, etc. —are not specific to energy efficiency but apply to other markets and types of products as well. In other domains, government research grants, tax incentives for private sector $\mathrm{R} \& \mathrm{D}$, and intellectual property protections are the primary tools used to encourage innovation, while anti-trust regulation aims to ameliorate problems associated with market concentration. There is not significant evidence to suggest that energy-efficiency markets exhibit particular failures that require remedies beyond these traditional innovation policies. And given the range of existing public policies in this realm (such as minimum efficiency standards, utility demand-side management programs, and public funding of research), it is unclear whether there are issues related to energy-efficient product variety, availability, and pricing distinct from many other types of products.

Better empirical evidence exists on the question of whether consumers lack adequate information regarding energy-efficient technologies, although relatively few studies attempt to disentangle the effects of imperfect information from competing explanations of consumer behavior. Nonetheless, lack of information is one of the most commonly-cited justifications for policy intervention in the market for energy-efficient products (Palmer et al. 2013, 272; Sanstad, Hanemann, and Auffhammer 2006, 6-9). A recent study designed to explore the relative importance of various elements of energy labels while controlling for other relevant factors, such as discounting behavior, found that providing simple information on the economic value of saving energy was the most important element guiding more cost-effective energy-efficiency decisions (Newell and Siikamäki 2013). Other information policies have also been documented to affect consumer decisions: In recent field experiments, giving households information about how their energy use compares to that of other, similar households has resulted in immediate and, to some degree, persistent reductions in energy use (Allcott 2011a; Allcott and Rogers 2012; Ayres, Raseman, and Shih 2013; Costa and Kahn 2013).

Past evidence in the United States and recent evidence from India suggests that imperfect information about energy use also exists among firms — and that firms may fail to undertake profitable efficiency investments because they are unaware of them (S. T. Anderson and Newell 2004; Bloom et al. 2011). Anderson and Newell (2004) examine industrial energy audits and find that while plants accept only half of recommended projects, most plants respond to the costs and benefits shown in energy audits and, with this information, adopt efficiency measures that meet standard investment criteria.

In theory and in practice, an informed third party can fill the information gap, as many government and private labeling programs seek to do. U.S. examples include EnergyGuide labels, Energy Star logos, automobile fuel economy labels, and various certification programs for residential and commercial buildings. A number of studies have analyzed the effect of such information policies. For example, 
Sallee (2013) highlights the possible supply distortions caused by coarse energy-efficiency certifications, such as the binary certification employed in the Energy Star program.

But the benefits of coarse certifications may outweigh supply distortions, given limits on consumer attention to detail about performance. Houde (2014a) evaluated the welfare effects of Energy Star and found that consumers rely heavily on the certification, indicating that the program does provide new information to the market. Similarly, Newell and Siikamaki (2013) found that the Energy Star logo significantly boosted the tendency for survey respondents to choose a more efficient appliance. However, Houde also found that some consumers over-rely on the binary label, in the sense that they do not consider actual energy savings, but only whether a product has the Energy Star label. This causes manufacturers to supply products that barely meet the certification threshold, potentially crowding out investments in higher efficiency products (Houde 2014b).

In the case of residential energy audits, past studies have found that few households seek the information, even when it is subsidized, and even fewer act on it (Berry 1993, 54; Tonn and Berry 1986, 785). On the other hand, studies have found that buildings certified by the Leadership in Energy and Environmental Design (LEED) and Energy Star programs retain higher value in rental and sales prices after accounting for other building characteristics (Eichholtz, Kok, and Quigley 2010, 2012). Similarly, residential certifications are associated with higher sales prices in both the Netherlands and the United States (Brounen and Kok 2011; Walls, Palmer, and Gerarden 2013).

Further research is needed to distinguish the effects of incomplete information from competing explanations of the energy gap and to evaluate the effectiveness and efficiency of current information policies. Research on the effectiveness of information presented online would be especially useful, because consumers increasingly obtain information and make purchases online.

\section{2) Are energy operating costs inefficiently priced and/or understood?}

Even if consumers make privately optimal decisions, energy-saving technology could diffuse more slowly than is socially optimal if energy prices fail to reflect the negative externalities (including climate impacts) associated with energy production and consumption. In other words, even if there is nothing paradoxical about firms' and individuals' decisions to forego energy-efficiency investments, an efficiency "gap" may still exist if energy prices are too low to stimulate the level of efficiency investment that would be justified taking into account all the costs of energy use to society as a whole.

Here again, the theoretical arguments are robust. But in contrast with explanations for the energy-

efficiency gap that focus on the availability and pricing of energy-efficient products, empirical evidence 
for the inefficient pricing of energy is considerable, and in some cases quite convincing. For example, studies that have sought to quantify the unpriced externalities of gasoline consumption estimate the costs of GHG emissions at 5-72 cents per gallon, assuming social costs of carbon between $\$ 20$ - \$300 per ton (Parry, Walls, and Harrington 2007, 377), while other analyses of the combined costs of local pollution, congestion, and accident externalities have arrived at estimates as high as $\$ 2.40$ per gallon (M. L. Anderson and Auffhammer 2013; Parry, Walls, and Harrington 2007). ${ }^{3}$

Quantitative estimates of the externalities associated with electricity use are more limited, and most of them do not account for upstream emissions and other damages that are location- and time-specific (Cullen 2013; Muller and Mendelsohn 2009; Zivin, Kotchen, and Mansur 2012). ${ }^{4}$ Coal- and natural gas-based electricity production have received the most attention, with estimates suggesting the social costs of (non-CO2) damages from coal-powered electricity, on average, are about 3-4 cents per kilowatt-hour $(\mathrm{kWh})$ and much less than 1 cent per $\mathrm{kWh}$ for natural gas-powered electricity (National Research Council 2010, 149). CO2 emissions from these sources approximately double these cost estimates, depending on choices of the social cost of carbon and discount rate. ${ }^{5}$

In general, the full incorporation of environmental externalities would likely raise electricity prices in most U.S. regions. However, many of these externalities are already regulated and thereby indirectlyand sometimes directly_ priced. But other market distortions — such as electricity price regulationmake it difficult to judge whether electricity prices are too low overall, and the answer seems certain to vary by region (and time of day). More research is needed to quantify and monetize electricity generation externalities, including comprehensive assessments of which externalities are currently unpriced or underpriced and which are effectively addressed by existing policy.

The fact that retail prices for electricity and natural gas are often set through economic regulation opens the door to a further possibility: that prices for these forms of energy are set too low (or too high) as a result of regulation (Davis and Muehlegger 2010; Naughton 1986). Here again, the evidence is mixed: On the one hand, the lack of time-varying pricing suggests that prices are too low during peak demand periods and too high during periods of low demand. This leads to inefficient utilization (Joskow and Wolfram 2012). Real-time electricity pricing could correct these incentive problems, particularly if consumers have access to real-time feedback on consumption (Jessoe and Rapson 2012), and could yield large efficiency gains for the electricity supply system as a whole (Borenstein 2005).

The figure of $\$ 2.40$ was presented by Soren Anderson, as part of preliminary research results and as an update to Parry, Walls, and Harrington (2007), at the October 2013 workshop on the energy-efficiency gap hosted by the Harvard Environmental Economics Program. It should be noted that some externalities, such as congestion, may be location- and/or time-dependent and optimally would be priced accordingly.

4 The research cited here also highlights the importance of taking into account these factors when forming policy and regulation.

5 Presentation by Karen Palmer at the October 2013 workshop hosted by the Harvard Environmental Economics Program, and subsequent communication. 
But the impact of time-of-use pricing on end-use efficiency investments is ambiguous (Gillingham, Newell, and Palmer 2009). Faced with real-time pricing, consumers might shift consumption to off-peak periods rather than invest in more efficient devices. (Indeed, if consumers can reduce their average electricity costs through load-shifting, real-time pricing might even reduce incentives for some efficiency investments.)

Yet another possibility is that consumers' expectations about future energy prices and/or energy use are systematically uninformed or biased downward: if consumers consistently underestimate their future energy needs and future energy prices, they are unlikely to make optimal energy-efficiency-investment decisions. Qualitative interviews suggest that people know current gasoline prices and tend to forecast future prices on that basis (Allcott 2011b, 102-103; S. T. Anderson, Kellogg, and Sallee 2011, 13-17). Given that people can be expected to have a good idea of their vehicle usage patterns and given that current gasoline prices have proved to be at least as good a predictor of future prices than other sources (such as econometric studies or fuel-price futures), it seems unlikely that systematic bias in consumer expectations about future fuel use and/or fuel prices account for the efficiency gap in motor vehicle energy use. On the other hand, some studies suggest that most car buyers lack the tools to value vehicle fuel economy (Turrentine and Kurani 2007).

Outside the transportation sector, limited evidence suggests consumers may be misinformed about current electricity prices, but there is no evidence of a systematic bias up or down. In terms of usage, experimental choice data suggest that consumers are also misinformed about how much electricity they use and how their daily activities translate into usage: consumers provided with real-time usage feedback become significantly more price responsive than consumers without such feedback (Jessoe and Rapson 2012). In addition, surveys indicate that consumers systematically overestimate the energy costs of low-usage goods (for example, computers) and underestimate the energy costs of high-usage goods (for example, water heaters) (Attari et al. 2010).

Though there is little evidence that systematic bias in consumer beliefs about future energy use and prices is a significant contributor to the efficiency gap, further research to understand the impact of these beliefs and to distinguish the effects of consumer beliefs from consumer preferences would be useful, especially if it helped isolate the effects of different types of information policies. The fact that existing pricing policies (e.g., fuel taxes, electricity rate structures) appear not to provide sufficient incentives for energy efficiency in many cases also suggests that further research is warranted.

Another potential explanation for the efficiency gap focuses on the possibility that analysts tend to overestimate the energy savings that can be achieved through efficiency investments. A number of studies have found that engineering-economic analyses, which rely on detailed information about 
the energy-use characteristics of different types of equipment, deployment levels, and usage patterns, typically produce estimates of energy savings that exceed the actual savings observed in impact evaluations that rely on after-the-fact energy consumption information.

This could be because the assumptions about usage and equipment performance used in engineeringeconomic analyses are incorrect or because the models fail to sufficiently account for complex interactions, such as the rebound effect or the free-rider problem. ${ }^{6}$ Thus, for example, a meta-analysis of 42 utility conservation programs found that actual, ex post energy savings from residential retrofit programs ranged from 15 to 117 percent of ex ante estimates (Nadel and Keating 1991). Savings from commercial retrofit programs ranged from 36 to 248 percent of engineering predictions, while a majority of programs failed to meet savings benchmarks (Nadel and Keating 1991). These direct comparisons suggest caution is warranted when interpreting ex ante engineering-economic evidence for the energy-efficiency gap. ${ }^{7}$

In other empirical research, two groups of participants in a utility weatherization program in the 1980s achieved 47 and 78 percent of predicted savings on average (Hirst 1986). ${ }^{8}$ Realized savings from another utility program ranged from 50 to 81 percent of predicted electricity savings, and 14-42 percent of predicted natural gas savings (Sebold and Fox 1985). Another study found that a tool used for weatherization home audits over-predicted savings by 186 percent, despite accurate engineering calculations (Ternes and Gettings 2008). Likewise, weatherization projects in New York State only achieved 57-69 percent of the savings predicted by the National Energy Audit Tool, and studies from other states reach qualitatively similar conclusions (Berry and Gettings 1998).

The persistence of analyses that significantly overestimate energy savings, despite substantial improvements in engineering-economic methods, suggests that there are significant opportunities for continued research in this area. In particular, more attention is needed to the transportation, commercial, and industrial sectors, because most evidence on these issues to date has come from the residential sector (likely because of the large number of programs that target this sector) —and because the characteristics of decision making in these sectors may be different from those in the residential sector. It is also possible that ex post evaluations have tended to focus on the studies that most exaggerated expected energy savings.

The "rebound effect" refers to the possibility that consumers will increase their use of more efficient products because of these products' lower operating costs. The "free-rider problem" refers to the possibility that some participants in incentive programs (such as utility programs that offer rebates for more efficient products) would have implemented the efficiency measure even without the incentive.

$7 \quad$ Nonetheless, they also found some cases in which ex ante analyses have underestimated energy savings.

8 Hirst (1986) reviews possible causes of the discrepancy between predicted and actual energy savings; examples include errors in methodology, errors in data collection and interpretation, failure of efficiency measures to perform as expected due to poor materials or installation, and changes in behavior. 
Another potential deficiency in many engineering-economic models is their failure to account for consumer heterogeneity - that is, the possibility that, for any technology, the benefits and costs of adoption can vary across potential adopters (Alberini, Bareit, and Filippini 2014, 33-4; Fowlie, Greenstone, and Wolfram 2014; Metcalf and Hassett 1999, 526; Newell and Siikamäki 2013). Even when engineering predictions correctly find that, on average, the benefits of adoption exceed the costs, this will not be true for some potential adopters. For example, (Hausman and Joskow 1982) point out that heterogeneity in usage profiles, capital stock, or preferences could result in realized savings below average predicted savings. Failure to model heterogeneity correctly can bias estimates of the size of the energy-efficiency gap. Moreover, the literature suggests that this bias is generally upward-in other words, ignoring consumer heterogeneity tends to produce overestimates of the magnitude of the energy-efficiency gap.

Palmer (2014) examines deficiencies of analytical approaches with regard to the U.S. Environmental Protection Agency's (EPA's) proposed rule issued in June 2014 that would reduce CO2 emissions from existing power plants. ${ }^{9}$ If implemented, this rule would have a significant impact on U.S. emissions, given that coal-fired power plants are the largest single class of CO2 emitters. The rule gives U.S. states flexibility in achieving specified emissions-reduction intensity targets, with increasing end-use efficiency as one of the means suggested. The EPA uses simple aggregate assumptions to estimate potential emissions-reductions from energy efficiency. Palmer proposes the incorporation of empirical evaluation into implementation plans, based on existing research such as that captured in this paper and with the goal of producing more realistic estimates of the potential of energy efficiency to reduce CO2 emissions.

\section{3) Are product choices cost-minimizing in present-value terms?}

This study, like the broader literature it reviews, starts from the premise that consumers and firmswhen considering whether to invest in an energy-efficiency improvement—are primarily motivated by the desire to minimize costs. Thus it is natural to ask whether product choices are cost-minimizing in present value terms, or whether various market failures and/or behavioral phenomena inhibit decisionmaking consistent with the goal of cost-minimization when it comes to energy-using products.

Problems of agency_or so-called "split incentives" — are among the most widely cited explanations for the energy-efficiency gap. Both terms refer to situations where the economic parties involved have different financial interests and face different incentives. Typical examples include landlord-tenant and

9 A "rule" in the United States is a regulation—promulgated by an executive agency under existing law, not newly-legislated by Congress.

Proposed rules are subject to comment and review before becoming a final rules (regulations). 
builder-buyer situations, in which the party making a capital investment in energy-using equipment (the landlord or builder) does not bear the cost of operating the equipment and therefore makes decisions that are not optimal from the perspective of the end user (the tenant or homebuyer). Similar agency conflicts are possible within firms when investment and operating decisions are divided among individuals or business units (Tietenberg 2009).

Empirical evidence has confirmed the existence of the principal-agent problem, and comprehensive accounting exercises have sought to estimate the potential importance of this market failure by quantifying the amount of energy consumption subject to incentive conflicts (International Energy Agency 2007). For example, 35 percent of U.S. residential energy use may be affected (Murtishaw and Sathaye 2006). Other research has compared owner-occupied and rental properties to directly estimate the impacts of split incentives. Most results are compelling: even after controlling for household income and other characteristics, renters are significantly less likely to have energy-efficient refrigerators, clothes washers, and dishwashers (Davis 2012). Conversely, owner-occupied dwellings in California are 13 and 20 percent more likely to have exterior wall and ceiling insulation (Gillingham, Harding, and Rapson 2012).

A related issue concerns the potential for information asymmetries that could further impede costminimizing decisions: to the extent that prospective tenants and homebuyers lack information about the energy characteristics of different properties, their rental or purchase decisions will fail to signal to landlords and builders that efficiency investments add value. Empirical studies lend support to this hypothesis: for example, data from the United States suggest that landlords include utilities in rental prices even when units are individually metered, in part because they cannot credibly communicate the cost-saving benefits of higher-efficiency units to prospective renters. ${ }^{10}$

In short, information asymmetries could explain why landlords do not make efficiency investments even when, as one survey in New Zealand found, tenants' willingness to pay higher rents in exchange for improved energy efficiency would seem to justify such investments (Phillips 2012). On the other hand, the magnitude of this market failure may be small, because the energy impacts of inefficient appliances and less insulation only amount to a few percent of total energy consumption in rental units (Davis 2012; Gillingham, Harding, and Rapson 2012). In addition, recent research on commercial buildings finds little evidence of asymmetric information between building owners and prospective buyers or tenants (Papineau 2013). 
While the best evidence on agency problems and information asymmetries comes from the residential sector, research confirms that firms are also susceptible to this type of market failure. Experience from Green Lights, a program that provides technical assistance to firms interested in efficient lighting upgrades, suggests that firms mostly failed to install cost-effective upgrades before the program due to capital rationing by managers and split incentives across divisions (Howarth, Haddad, and Paton 2000). Likewise, case studies in Europe identified split incentives as a barrier to investments in more efficient electric motors (de Almeida 1998; Ostertag 2003).

Another set of possible explanations for the efficiency gap centers on social learning and peer effects: the possibility that consumers look to the purchasing decisions and subsequent experience of other consumers when making decisions about whether to adopt a given technology. For example, if consumers delay adopting a new technology because they want to learn from the experience of other adopters, this informational or "learning-by-using" spillover effect could slow the diffusion of energyefficient products and contribute to the efficiency gap. Research in other domains finds that social learning and peer effects are important, but there is less evidence on the role they play in the diffusion of energy-efficiency technologies. ${ }^{11}$ In general, credibly identifying spillovers using observational data is challenging, given the difficulty of disentangling these effects from other unobservable factors in consumers' decision making (Foster and Rosenzweig 2010; Manski 1993; Narayanan and Nair 2013). ${ }^{12}$ And even where it is possible to test whether consumers delay adoption due to spillover effects, further research would be needed to determine how much this phenomenon contributes to the efficiency gap (Baird et al. 2014).

By contrast, considerable evidence exists that consumers are simply inattentive to energy costs when purchasing energy-using products. Put another way, these costs are not a salient part of their purchasing decisions. In some markets, the effects of inattention could be substantial. For example, almost half of surveyed vehicle buyers report making their decisions without considering fuel costs (Allcott 2011b, 100). More generally, many consumers may focus more on upfront purchasing costs than on longerterm operating costs: other research finds, for example, that consumers largely ignored replacement ink prices when making printer purchase decisions (Hall 1997). This lack of attention is not necessarily irrational: intuition suggests that consumers will only pay attention to an attribute if the expected benefits of being informed about that attribute outweigh the cognitive costs of acquiring information.

11 Most evidence on the role of learning spillovers comes from research on the introduction of hybrid vehicles, which finds that such spillovers can discourage as well as encourage technology adoption: higher market penetration by the Toyota Prius led to increased adoption of all hybrids, while higher market penetration by the Honda Insight led to reduced adoption (Heutel and Muehlegger 2013).

12 In the residential sector, a study of homebuilders' choices of thermal insulation found no evidence of large knowledge externalities, suggesting builders do not learn from the adoption of efficient technologies by competitors. An alternative explanation is that builders have complete (or nearly complete) information, so there is no scope for learning from the adoption decisions of others (Jaffe and Stavins 1995). 
Modeling inattention to energy efficiency as a result of costly information acquisition offers one way to explain decisions that may otherwise appear to be privately sub-optimal (Howarth and Andersson 1993; Sallee 2013).

A number of research methods have been used to explore the effects of inattention, from approaches that attempt to model the decision-making process to studies that attempt to estimate attentiveness using empirical data (for example by comparing demand elasticities for efficient products with respect to prices and energy costs). Other research has relied on field experiments: for example, in one study an online intervention to increase consumers' attention to energy use increased average willingness to pay for compact fluorescent light bulbs (CFLs) by more than two dollars, while an in-store intervention had no statistically significant effect on CFL demand (Allcott and Taubinsky 2013). Stated choice experiments that vary the type of information available to consumers can also help assess which considerations are most salient to consumers (Newell and Siikamäki 2013). Each of these research methods has limitations, however, and it remains difficult to distinguish the effects of inattention from other factors.

Economic theory and empirical research provide some guidance for policy to counter the effects of inattention with respect to the adoption of energy-efficiency technologies. Information programs could target consumers who have biased beliefs or are inattentive to future energy costs. Policies can also lower the cost of attention, and even coarse policies_-such as simple certification programs_could be justified if they lower the cost of attention sufficiently (Houde 2014a; Houde 2014b; Sallee 2013, 32; Sallee and Slemrod 2012). In some cases, the effects of inattention may bolster the case for market price interventions; an increase in energy prices, besides correcting the market failure that results when prices do not reflect environmental and other externalities, would likely cause consumers to pay more attention to energy use characteristics (Allcott, Mullainathan, and Taubinsky 2012). Minimum efficiency standards are another widely used policy intervention; such programs can have the effect of removing the most inefficient products from the market altogether.

Research in psychology points to other factors that could inhibit energy-efficient purchasing decisions. These include the influence of loss-aversion (i.e., people's tendency to prefer avoiding losses to acquiring gains) and reference points (i.e., people's tendency to value product attributes relative to their expectations rather than in absolute terms). Survey evidence on consumer demand for fuel economy in vehicles is consistent with loss aversion (Greene, Evans, and Hiestand 2013), while experimental research on energy use (Allcott 2011a; Goldstein, Cialdini, and Griskevicius 2008) lends support to the importance of reference points. For example, in three experiments, replacing incandescent light bulbs with more efficient CFLs as the default significantly increased the proportion of subjects who chose CFLs (Dinner et al. 2011). Overall, however, little is known about the impacts of loss aversion and 
reference points on energy-efficiency investments, and more empirical research is needed to quantify their importance.

Yet another possible explanation for the energy-efficiency gap is that cognitive limitations prevent people (and perhaps firms) from properly balancing present value benefits and costs when investing in energy-using goods (Gillingham, Newell, and Palmer 2009). Studies of vehicle fuel economy provide some evidence for these limitations (which are also known in the economics literature as "bounded rationality"), finding that consumers systematically misperceive the information contained in fuel economy ratings, due to the inverse relationship between gasoline consumption and miles per gallon (Larrick and Soll 2008; Allcott 2013). Other research has shown that stated preferences for cars of various efficiencies depend on the metric and scale of information provided on energy labels (Camilleri and Larrick 2014).

Translations of fuel economy into multiple perfectly-correlated metrics (that is, gallons per mile, estimated annual fuel cost, and greenhouse gas rating) and scaling these metrics over the vehicle lifetime alter stated preferences - a finding that may point to useful policy changes, such as tailoring the scale of energy labels based on the expected lifetime of a given product or providing multiple translations of energy-efficiency metrics (Camilleri and Larrick 2014; Ungemach et al. 2014). ${ }^{13}$ Ungemach and colleagues have also found that study participants' likelihood of selecting the fuel-efficient option was affected by their pro-environmental attitudes, but only when the translated fuel-efficiency attributes included the greenhouse gas rating.

A related question is whether myopia or short-sightedness inhibits energy-efficient decisions: that is, whether consumers' time horizons for valuing the cost savings associated with lower energy use are too short to justify the added upfront cost of more efficient products. Efforts to calculate the implicit discount rate that consumers and firms apply to energy-efficiency investments date back decades, with a seminal 1979 study of this issue finding implicit discount rates in excess of 20 percent-far higher than market interest rates (Hausman 1979). Subsequent studies reached similar conclusions, but the more difficult challenge has been to distinguish the effects of myopia from other possible explanations (Newell and Siikamäki 2013). For example, a homeowner may apply a high discount rate to homeefficiency improvements to insulate against the risk that these improvements will not be installed correctly (Giraudet and Houde 2014).

Automobile purchases provide a good setting to study these questions because such purchases are major decisions, about which consumers presumably think carefully, and because the cost of gasoline has varied substantially over time (Helfand and Wolverton 2011). One study found that consumers are

13 To some extent, this is already happening: new vehicle labels in the United States were recently redesigned to include gallons per miles, multiple cost estimates, comparisons with vehicle class, and environmental ratings (U.S. Environmental Protection Agency 2014). 
indifferent between $\$ 0.76$ now and $\$ 1.00$ of discounted future gasoline expenditures, suggesting the possibility of myopia or undervaluation of fuel economy (Allcott and Wozny 2013). On the other hand, other studies find that market outcomes are consistent with dynamically cost-minimizing behavior (Busse, Knittel, and Zettelmeyer 2013; Sallee, West, and Fan 2009). Evidence from gasoline and diesel car purchases in Europe in the early 1990s suggests an implicit discount rate of about 11.5 percent, only slightly above automobile loan rates at the time (Verboven 2002, 288). However, research has not always taken into account that car markets have been subject to fuel economy regulation for many years, which tends to reduce the possibility for high implicit discount rates.

Capital market failures could explain a divergence between estimated implicit discount rates and typical market interest rates. Prospective investors facing capital constraints may be unable to finance energyefficiency investments, even if future returns would justify the up-front cost. This could result in an estimated implicit discount rate that is above normal market rates. Information asymmetries could prevent efficient lending even for collateralized investments: firms that possess private information about future cost savings from a particular investment may be unable to convince lenders of its financial potential if the savings are costly for the lender to evaluate. In the future, theoretical and empirical findings from consumer finance research may shed light on the specific capital market failures that are most important for energy efficiency. However, it may remain difficult to distinguish the effect of capital market failures from a lack of underlying demand for energy-saving technology (Palmer, Walls, and Gerarden 2012, 29-30).

Option value - the benefit of delaying an investment even when its net present value is positivegenerally factors into decisions that involve uncertainty, irreversible investment, and timing flexibility (Dixit and Pindyck 1994). Consumers and firms commonly face these types of decisions when investing in energy-consuming durable goods with little or no resale value. In these situations, the combination of uncertainty about future energy prices and uncertainty about future technological innovation could increase the option value of delaying an efficiency investment, even if that investment seems worthwhile at present. Other relevant sources of uncertainty include future product use, product efficiency, and product life (Greene 2011).

On the other hand, the option value of delay is unlikely to play a large role in many energy-related purchases. First, not all energy-efficient investments are irreversible, since there are active resale markets for many types of consumer goods. Uncertainty about future energy prices may be irrelevant, as in the case of firms with long-term energy supply contracts. In other cases, uncertainty may be relatively unimportant, as with energy-consuming goods with relatively short lifetimes (for example, light bulbs). Finally, the timing of investments in energy-consuming durables is not always flexible (for example, the replacement of a broken water heater). 
Overall, evidence on this issue is mixed. Energy-price uncertainty ranked fourth out of 15 reported reasons firms did not undertake energy-efficiency investments recommended by auditors in a survey of small- and medium-sized businesses (Fleiter, Schleich, and Ravivanpong 2012). A stated preference choice experiment in the residential sector revealed a correlation between energy price uncertainty and a preference for the status quo over energy-efficiency improvements (Alberini, Banfi, and Ramseier 2013), confirming the basic prediction of the option value model, but not quantifying its relative importance.

\section{4) Do other unobserved costs inhibit energy-efficient decisions?}

A fourth category of explanations for the energy-efficiency gap concerns the possibility that other costs not typically considered in engineering and economic analyses inhibit more energy-efficient decisions. A first question is whether analysts take sufficient account of product attributes. If products of varying efficiencies differ from each other in ways that are often omitted by engineering and econometric analysis but that are important to consumers, this could readily contribute to the misidentification of an energy-efficiency gap (Houde 2013). For example, producers may generate efficiency improvements by trading off other product attributes, potentially reducing product quality in the eyes of consumers. Ignoring these trade-offs would bias estimates of consumer choice and welfare. One prominent study treated CFLs as interchangeable with other forms of lighting (Granade et al. 2009), thus ignoring a potentially important source of (unobserved) opportunity costs. In principle, econometric methods can address these issues by including product attributes in analyses of choice data, but in practice, these methods have been limited by the impracticality of observing and accurately measuring all product characteristics.

Another possibility is that analysts fail to take sufficient account of the costs of implementing energyefficiency improvements. Such costs could take many forms: time spent researching product alternatives; unobserved implementation costs; and the costs of reallocating resources within a firm. Costs that are less-easily quantified are more likely to be omitted by analysts (Granade et al. 2009; Huntington 2011) but they can nonetheless act as real barriers to investment - not optimization errors or market failures - and should be included in an unbiased analysis of the energy-efficiency gap.

Consumers often face a set of adoption costs beyond the obvious costs of purchasing and installing more efficient technologies. For example, homeowners have attributed the decision not to install or upgrade attic insulation to the unpleasantness of clearing stored items from the attic space (Caird, Roy, and Herring 2008). A policy experiment in the United Kingdom found that lowering such costs by offering attic cleaning would increase insulation investments (U.K. Department of Energy and 
Climate Change 2013, 4-5). Another study estimated U.S. homeowners perceive the opportunity costs of installing thermal insulation to be more than twice the costs of materials and labor (Sharma 2011).

In the commercial and industrial sectors, case studies and survey evidence provide the bulk of the empirical evidence (Fleiter, Schleich, and Ravivanpong 2012), with firms indicating that production disruptions and inconvenience can preclude efficiency investments (Rohdin and Thollander 2006; Thollander and Ottosson 2008). Survey respondents also cite lack of time as a barrier, highlighting the role of opportunity cost in simply considering investments (Schleich 2009; Sorrell et al. 2004; Thollander, Danestig, and Rohdin 2007; Trianni and Cagno 2012). Similarly, recipients of industrial energy audits who failed to undertake recommended investments attributed their decisions to unmeasured costs and risks not considered in the audit analysis (S. T. Anderson and Newell 2004). In principle, there is no reason analysts cannot incorporate these additional costs in analyses, but data and measurement challenges often inhibit their ability to do so.

We find that the empirical evidence in this realm is sound and that the data exist to further explore these questions. Hence we assign a relatively high priority to research, in particular to aid understanding of consumer demand (willingness to pay) for product attributes, which can be useful for evaluating and designing regulatory approaches.

\section{CONCLUSION}

This paper examined a number of possible explanations for the "energy-efficiency gap," the apparent phenomenon that some energy-efficiency technologies that would pay off for adopters financially are nevertheless not adopted, as well as the broader phenomenon that some energy-efficiency technologies that would be socially efficient—including contributing to the mitigation of GHG emissions — are not adopted.

To sort the evidence on causes of this gap — and indeed to assess the extent to which the gap is realwe explored a series of questions about the availability and price of energy-efficient products, about the pricing of energy itself, about consumers' tendency (or not) to make cost-minimizing product choices, and about the existence of unobserved costs that could factor into energy-efficiency investment decisions.

On the question of whether current energy-efficient product offerings are optimal, we find that empirical evidence is generally limited, though more data are becoming available. However, we do not see this area as meriting high priority for future research, with the exception of further research to evaluate the effectiveness of existing and proposed energy-efficiency information policies. 
By contrast, stronger empirical evidence exists for the inefficiency of energy prices (in the sense that prices do not capture all the negative externalities of energy use, including climate-change impacts) and for the presence of unobserved costs that influence consumer and firm decision-making. In both these areas, data are likely to be available for conducting further research, and existing policies to address factors that inhibit cost-effective efficiency investment appear not to be sufficient. Under the set of issues that could influence consumers' ability to make cost-minimizing product choices, the authors find strong evidence for the importance of some factors (notably, split incentives/agency issues and inattention/salience) and weak to moderate evidence for others. Importantly, the bulk of previous work on these issues has focused on the residential sector, with much less attention given to the commercial and industrial sectors.

Overall, we conclude that theoretically sound explanations for individuals' and firms' apparent underinvestment in energy-efficient technologies can be found in each of the categories cited in economics research: market failures, behavioral effects, and modeling flaws. Limited empirical evidence also exists for each of these categories of explanations, although this evidence is by no means consistently strong for each of the specific explanations.

Given the many energy-efficiency policies and programs that are already in place, priority should be given to research that evaluates the effectiveness, cost-effectiveness, and economic efficiency of existing policies, as well as options for their improvement. Further empirical research and analysis would be especially useful in the following areas: energy pricing and externalities; split incentives and agency issues in areas where efficiency standards are not present; and behavioral issues, including a better understanding of consumer responsiveness to price incentives and other polices, as well as demand for product attributes that are correlated with energy efficiency. Such research could help inform future policy_including climate-change policy_and product development decisions. 


\section{REFERENCES}

Alberini, Anna, Silvia Banfi, and Celine Ramseier. 2013. "Energy Efficiency Investments in the Home: Swiss Homeowners and Expectations about Future Energy Prices.” The Energy Journal 34 (1). http://dx.doi.org/10.5547/01956574.34.1.3.

Alberini, Anna, Markus Bareit, and Massimo Filippini. 2014. Does the Swiss Car Market Reward Fuel Efficient Cars? Evidence from Hedonic Pricing Regressions, Matching and a Regression Discontinuity Design. Working Paper 14/190. Economics Working Paper Series. Zurich, Switzerland: Center of Economic Research at ETH Zurich. www.cer.ethz.ch/research/WP-14190.pdf.

Allcott, Hunt. 2011a. "Social Norms and Energy Conservation." Journal of Public Economics 95 (910): 1082-95. http://dx.doi.org/10.1016/j.jpubeco.2011.03.003.

- 2011b. "Consumers' Perceptions and Misperceptions of Energy Costs." American Economic Review 101 (3): 98-104. http://dx.doi.org/10.1257/aer.101.3.98.

—. 2013. "The Welfare Effects of Misperceived Product Costs: Data and Calibrations from the Automobile Market." American Economic Journal: Economic Policy 5 (3): 30-66. http:// dx.doi.org/10.1257/pol.5.3.30.

Allcott, Hunt, Sendhil Mullainathan, and Dmitry Taubinsky. 2012. Energy Policy with Externalities and Internalities. NBER Working Paper 17977. www.nber.org/papers/w17977.

Allcott, Hunt, and Todd Rogers. 2012. The Short-Run and Long-Run Effects of Behavioral Interventions: Experimental Evidence from Energy Conservation. Working Paper 18492. National Bureau of Economic Research. www.nber.org/papers/w18492.

Allcott, Hunt, and Dmitry Taubinsky. 2013. The Lightbulb Paradox: Evidence from Two Randomized Experiments. Working Paper 19713. National Bureau of Economic Research. www.nber.org/ papers/w19713.

Allcott, Hunt, and Nathan Wozny. 2013. "Gasoline Prices, Fuel Economy, and the Energy Paradox." Review of Economics and Statistics, October. http://dx.doi.org/10.1162/REST_a_00419.

Anderson, Michael L., and Maximilian Auffhammer. 2013. "Pounds That Kill: The External Costs of Vehicle Weight." The Review of Economic Studies 81 (2): 535-571. http://dx.doi.org/10.1093/ restud/rdt035. 
Anderson, Soren T., Ryan Kellogg, and James M. Sallee. 2011. What Do Consumers Believe About Future Gasoline Prices?. Working Paper 16974. National Bureau of Economic Research. www. nber.org/papers/w16974.

Anderson, Soren T., and Richard G. Newell. 2004. "Information Programs for Technology Adoption: The Case of Energy-Efficiency Audits." Resource and Energy Economics 26 (1): 27-50. http://dx.doi.org/10.1016/j.reseneeco.2003.07.001.

Attari, Shahzeen Z., Michael L. DeKay, Cliff I. Davidson, and Wändi Bruine de Bruin. 2010. "Public Perceptions of Energy Consumption and Savings." Proceedings of the National Academy of Sciences 107 (37): 16054-59. http://dx.doi.org/10.1073/pnas.1001509107.

Ayres, Ian, Sophie Raseman, and Alice Shih. 2013. "Evidence from Two Large Field Experiments That Peer Comparison Feedback Can Reduce Residential Energy Usage.” Journal of Law, Economics, and Organization 29 (5): 992-1022. http://dx.doi.org/10.1093/jleo/ews020.

Baird, Sarah, Aislinn Bohren, Craig McIntosh, and Berk Ozler. 2014. "Designing Experiments to Measure Spillover Effects.” Working Paper. University of California, San Diego. http://irps. ucsd.edu/assets/001/505310.pdf.

Berry, Linda G. 1993. "A Review of the Market Penetration of US Residential and Commercial Demand-Side Management Programmes.” Energy Policy 21 (1): 53-67. http://dx.doi. org/10.1016/0301-4215(93)90208-W.

Berry, Linda G., and Michael B. Gettings. 1998. "Realization Rates of the National Energy Audit." In Thermal Performance of the Exterior Envelopes of Buildings VII Conference, 7-11. www.ornl. gov/sci/buildings/2012/1998\%20B7\%20papers/058_Berry.pdf.

Bloom, Nicholas, Benn Eifert, Aprajit Mahajan, David McKenzie, and John Roberts. 2011. Does Management Matter? Evidence from India. Working Paper 16658. Cambridge, MA: National Bureau of Economic Research. www.nber.org/papers/w16658.

Borenstein, Severin. 2005. “The Long-Run Efficiency of Real-Time Electricity Pricing.” The Energy Journal 26 (3). http://dx.doi.org/10.5547/ISSN0195-6574-EJ-Vol26-No3-5.

Brounen, Dirk, and Nils Kok. 2011. "On the Economics of Energy Labels in the Housing Market." Journal of Environmental Economics and Management 62 (2): 166-79. http://dx.doi. org/10.1016/j.jeem.2010.11.006. 
Busse, Meghan R, Christopher R Knittel, and Florian Zettelmeyer. 2013. "Are Consumers Myopic? Evidence from New and Used Car Purchases." American Economic Review 103 (1): 220-56. http://dx.doi.org/10.1257/aer.103.1.220.

Caird, Sally, Robin Roy, and Horace Herring. 2008. "Improving the Energy Performance of UK Households: Results from Surveys of Consumer Adoption and Use of Low- and ZeroCarbon Technologies." Energy Efficiency 1 (2): 149-66. http://dx.doi.org/10.1007/s12053008-9013-y.

Camilleri, Adrian R., and Richard P. Larrick. 2014. "Metric and Scale Design as Choice Architecture Tools." Journal of Public Policy \& Marketing 33 (1): 108-25.

Costa, Dora L., and Matthew E. Kahn. 2013. “Energy Conservation 'nudges' and Environmentalist Ideology: Evidence from a Randomized Residential Electricity Field Experiment.” Journal of the European Economic Association 11 (3): 680-702. http://dx.doi.org/10.1111/jeea.12011.

Cullen, Joseph. 2013. "Measuring the Environmental Benefits of Wind-Generated Electricity." American Economic Journal: Economic Policy 5 (4): 107-33. http://dx.doi.org/10.1257/ pol.5.4.107.

Davis, Lucas W. 2012. "Evaluating the Slow Adoption of Energy Efficient Investments: Are Renters Less Likely to Have Energy Efficient Appliances?” In The Design and Implementation of U.S. Climate Policy, edited by Don Fullerton and Catherine Wolfram. University of Chicago Press. www.nber.org/chapters/c12130.pdf.

Davis, Lucas W., and Erich Muehlegger. 2010. "Do Americans Consume Too Little Natural Gas? An Empirical Test of Marginal Cost Pricing." The RAND Journal of Economics 41 (4): 791-810. www.jstor.org/stable/25746054.

De Almeida, Edmar Luiz Fagundes. 1998. "Energy Efficiency and the Limits of Market Forces: The Example of the Electric Motor Market in France.” Energy Policy 26 (8): 643-53. http:// dx.doi.org/10.1016/S0301-4215(98)00023-8.

Dinner, Isaac, Eric J. Johnson, Daniel G. Goldstein, and Kaiya Liu. 2011. "Partitioning Default Effects: Why People Choose Not to Choose." Journal of Experimental Psychology: Applied 17 (4): 332-41. http://dx.doi.org/10.1037/a0024354.

Dixit, Avinash K., and Robert S. Pindyck. 1994. Investment under Uncertainty. Princeton University Press. 
Eichholtz, Piet, Nils Kok, and John Quigley. 2010. “Doing Well by Doing Good? Green Office Buildings." American Economic Review 100 (5): 2494-2511. http://dx.doi.org/10.1257/ aer.100.5.2492.

- 2012. "The Economics of Green Building." Review of Economics and Statistics 95 (1): 50-63. http://dx.doi.org/10.1162/REST_a_00291.

Fleiter, Tobias, Joachim Schleich, and Ployplearn Ravivanpong. 2012. "Adoption of EnergyEfficiency Measures in SMEs_-An Empirical Analysis Based on Energy Audit Data from Germany." Energy Policy 51 (December): 863-75. http://dx.doi.org/10.1016/j. enpol.2012.09.041.

Foster, Andrew D., and Mark R. Rosenzweig. 2010. "Microeconomics of Technology Adoption." Annual Review of Economics 2 (1): 395-424. http://dx.doi.org/10.1146/annurev. economics.102308.124433.

Fowlie, Meredith, Michael Greenstone, and Catherine Wolfram. 2014. "An Experimental Evaluation of the Weatherization Assistance Program.” In preparation.

Gillingham, Kenneth, Matthew Harding, and David Rapson. 2012. "Split Incentives in Residential Energy Consumption.” The Energy Journal 33 (2): 37-62. http://dx.doi. org/10.5547/01956574.33.2.3.

Gillingham, Kenneth, Richard G. Newell, and Karen L. Palmer. 2009. "Energy Efficiency Economics and Policy." Annual Review of Resource Economics 1 (June): 597-620. http:// dx.doi.org/10.1146/annurev.resource.102308.124234.

Giraudet, Louis-Gaëtan, and Sébastien Houde. 2014. Double Moral Hazard and the Energy Efficiency Gap. Working Paper 009. Berkeley, California: Evidence for Action on Energy Efficiency (E2e). http://e2e.haas.berkeley.edu/pdf/workingpapers/WP009.pdf\#page=1.

Goldstein, Noah J., Robert B. Cialdini, and Vladas Griskevicius. 2008. "A Room with a Viewpoint: Using Social Norms to Motivate Environmental Conservation in Hotels." Journal of Consumer Research 35 (3): 472-82. http://dx.doi.org/10.1086/586910.

Granade, Hannah Choi, John Creyts, Anton Derkach, Philip Farese, Scott Nyquist, and Ken Ostrowski. 2009. Unlocking Energy Efficiency in the U.S. Economy. McKinsey \& Company. http://www.mckinsey.com/client_service/electric_power_and_natural_gas/latest_thinking/ unlocking_energy_efficiency_in_the_us_economy. 
Greene, David L. 2011. "Uncertainty, Loss Aversion, and Markets for Energy Efficiency." Energy Economics 33 (4): 608-16. http://dx.doi.org/10.1016/j.eneco.2010.08.009.

Greene, David L., David H. Evans, and John Hiestand. 2013. "Survey Evidence on the Willingness of U.S. Consumers to Pay for Automotive Fuel Economy." Energy Policy 61 (October): 1539-50. http://dx.doi.org/10.1016/j.enpol.2013.05.050.

Hall, Robert. 1997. The Inkjet Aftermarket: An Economic Analysis. Stanford University. www.stanford. edu/ - rehall/Inkjet\%20Aftermarket\%201997.pdf.

Hausman, Jerry A. 1979. "Individual Discount Rates and the Purchase and Utilization of EnergyUsing Durables." Bell Journal of Economics 10 (1): 33. http://dx.doi.org/10.2307/3003318.

Hausman, Jerry A., and Paul L. Joskow. 1982. "Evaluating the Costs and Benefits of Appliance Efficiency Standards." The American Economic Review 72 (2): 220-25. www.jstor.org/ stable/1802332.

Helfand, Gloria, and Ann Wolverton. 2011. "Evaluating the Consumer Response to Fuel Economy: A Review of the Literature." International Review of Environmental and Resource Economics 5 (2): 103-46. http://dx.doi.org/10.1561/101.00000040.

Heutel, Garth, and Erich Muehlegger. 2013. "Consumer Learning and Hybrid Vehicle Adoption.” Working Paper. Georgia State University. http://www.uncg.edu/bae/people/heutel/Papers/ Hybrids_Heutel_Muehlegger.pdf.

Hirst, Eric. 1986. "Actual Energy Savings after Retrofit: Electrically Heated Homes in the Pacific Northwest." Energy 11 (3): 299-308. http://dx.doi.org/10.1016/0360-5442(86)90088-5.

Houde, Sébastien. 2013. "Do EE Analysts Take Sufficient Account of Product Attributes That Are Inferior for EE Products?” Prepared for “Evaluating the Energy Efficiency Gap," a research workshop hosted by the Harvard Environmental Economics Program. Cambridge, Massachusetts. www.hks.harvard.edu/m-rcbg/heep/ee-workshop_131024-25/supp/4.a-b\%20 Houde\%20130919/Note_EEGap_InferiorProduct_Attributes_v2.pdf.

- 2014a. How Consumers Respond to Environmental Certification and the Value of Energy Information. Working Paper 20019. National Bureau of Economic Research. www.nber.org/ papers/w20019. 
- 2014b. Bunching with the Stars: How Firms Respond to Environmental Certification. Working Paper. University of Maryland. http://terpconnect.umd.edu/ -shoude/EnergyStarFirmsHoude_ May2014.pdf.

Howarth, Richard B., and Bo Andersson. 1993. "Market Barriers to Energy Efficiency." Energy Economics 15 (4): 262-72. http://dx.doi.org/10.1016/0140-9883(93)90016-K.

Howarth, Richard B., Brent M. Haddad, and Bruce Paton. 2000. "The Economics of Energy Efficiency: Insights from Voluntary Participation Programs.” Energy Policy 28 (6-7): 477-86. http://dx.doi.org/10.1016/S0301-4215(00)00026-4.

Huntington, Hillard G. 2011. “The Policy Implications of Energy-Efficiency Cost Curves.” Energy Journal 32 (Special Issue): 7-21. http://dx.doi.org/10.5547/ISSN0195-6574-EJ-Vol32NoSI-2.

Huntington, Hillard G., and Eric Smith. 2011. "Mitigating Climate Change through Energy Efficiency: An Introduction and Overview.” Energy Journal 32 (Special Issue): 1-6. http:// dx.doi.org/10.5547/ISSN0195-6574-EJ-Vol33-SI1-1.

International Energy Agency. 2007. Mind the Gap: Quantifying Principal-Agent Problems in Energy Efficiency. Paris: International Energy Agency. http://www.iea.org/publications/ freepublications/publication/mind_the_gap.pdf.

Jaffe, Adam B., and Robert N. Stavins. 1995. "Dynamic Incentives of Environmental Regulations: The Effects of Alternative Policy Instruments on Technology Diffusion.” Journal of Environmental Economics and Management 29 (3): 43-63. http://dx.doi.org/10.1006/ jeem.1995.1060.

Jessoe, Katrina, and David Rapson. 2012. Knowledge Is (Less) Power: Experimental Evidence from Residential Energy Use. Working Paper 18344. National Bureau of Economic Research. http:// www.nber.org/papers/w18344.

Joskow, Paul L., and Catherine D. Wolfram. 2012. "Dynamic Pricing of Electricity." American Economic Review 102 (3): 381-85. http://dx.doi.org/10.1257/aer.102.3.381.

Kamien, Morton I., and Nancy L. Schwartz. 1982. Market Structure and Innovation. Cambridge University Press. 
Larrick, Richard P., and Jack B. Soll. 2008. “The MPG Illusion.” Science 320 (5883): 1593-94. http://dx.doi.org/10.1126/science.1154983.

Manski, Charles F. 1993. "Identification of Endogenous Social Effects: The Reflection Problem.” The Review of Economic Studies 60 (3): 531-42. http://dx.doi.org/10.2307/2298123.

Metcalf, Gilbert E., and Kevin A. Hassett. 1999. "Measuring the Energy Savings from Home Improvement Investments: Evidence from Monthly Billing Data." Review of Economics and Statistics 81 (3): 516-28. http://dx.doi.org/10.1162/003465399558274.

Muller, Nicholas Z., and Robert Mendelsohn. 2009. "Efficient Pollution Regulation: Getting the Prices Right." The American Economic Review 99 (5): 1714-39. http://dx.doi.org/10.1257/ aer.99.5.1714.

Murtishaw, Scott, and Jayant Sathaye. 2006. Quantifying the Effect of the Principal-Agent Problem on US Residential Energy Use. LBNL-59773. Berkeley, California: Lawrence Berkeley National Laboratory. http://escholarship.org/uc/item/6f14t11t\#page-1.

Nadel, Steven, and Kenneth Keating. 1991. Engineering Estimates vs. Impact Evaluation Results: How Do They Compare and Why? Research Report U915. Washington, D. C.: American Council for an Energy-Efficient Economy. www.aceee.org/research-report/u915.

Narayanan, Sridhar, and Harikesh S. Nair. 2013. "Estimating Causal Installed-Base Effects: A Bias-Correction Approach.” Journal of Marketing Research 50 (1): 70-94. http://dx.doi. org/10.1509/jmr.11.0183.

National Research Council. 2010. Hidden Costs of Energy: Unpriced Consequences of Energy Production and Use. Washington, D. C.: The National Academies Press. www.nap.edu/catalog. php?record_id=12794.

Naughton, Michael C. 1986. "The Efficiency and Equity Consequences of Two-Part Tariffs in Electricity Pricing." The Review of Economics and Statistics 68 (3): 406-14. http://dx.doi. org/10.2307/1926017.

Newell, Richard G., and Juha V. Siikamäki. 2013. Nudging Energy Efficiency Behavior: The Role of Information Labels. Working Paper 19224. National Bureau of Economic Research. www.nber. org/papers/w19224. 
Ostertag, Katrin. 2003. No-Regret Potentials in Energy Conservation: An Analysis of Their Relevance, Size and Determinants. Series of the Fraunhofer Institute for Systems and Innovation Research 15. Heidelberg, Germany: Physica-Verlag.

Palmer, Karen L. 2014. “Energy Efficiency in 111(d): Understanding Building Block \#4.” Common Resources (RFF). June 16. http://common-resources.org/2014/energy-efficiency-in-111dunderstanding-building-block-4/.

Palmer, Karen L., Margaret Walls, and Todd Gerarden. 2012. Borrowing to Save Energy: An Assessment of Energy-Effciency Financing Programs. Washington, D.C.: Resources for the Future. www.rff.org/RFF/Documents/RFF-Rpt-Palmeretal\%20EEFinancing.pdf.

Palmer, Karen L., Margaret Walls, Hal Gordon, and Todd Gerarden. 2013. "Assessing the EnergyEfficiency Information Gap: Results from a Survey of Home Energy Auditors.” Energy Efficiency 6 (2): 271-92. http://dx.doi.org/10.1007/s12053-012-9178-2.

Papineau, Maya. 2013. Energy Codes and the Landlord-Tenant Problem. Working Paper. Carleton University. http://escholarship.org/uc/item/2bq3x1t6\#page-1

Parry, Ian W. H, Margaret Walls, and Winston Harrington. 2007. "Automobile Externalities and Policies." Journal of Economic Literature 45 (2): 373-99. http://dx.doi.org/10.1257/ jel.45.2.373.

Phillips, Yvonne. 2012. "Landlords versus Tenants: Information Asymmetry and Mismatched Preferences for Home Energy Efficiency.” Energy Policy 45 (June): 112-21. http://dx.doi. org/10.1016/j.enpol.2012.01.067.

Rohdin, P., and P. Thollander. 2006. "Barriers to and Driving Forces for Energy Efficiency in the Non-Energy Intensive Manufacturing Industry in Sweden.” Energy 31 (12): 1836-44. http:// dx.doi.org/10.1016/j.energy.2005.10.010.

Sallee, James M. 2013. Rational Inattention and Energy Efficiency. Working Paper 19545. National Bureau of Economic Research. www.nber.org/papers/w19545.

Sallee, James M., and Joel Slemrod. 2012. "Car Notches: Strategic Automaker Responses to Fuel Economy Policy." Journal of Public Economics 96 (11-12): 981-99. http://dx.doi. org/10.1016/j.jpubeco.2012.06.005. 
Sallee, James M., Sarah E. West, and Wei Fan. 2009. “The Effect of Gasoline Prices on the Demand for Fuel Economy in Used Vehicles: Empirical Evidence and Policy Implications." Chicago, Illinois. http://home.uchicago.edu/ sallee/salleewest_091208.pdf.

Sanstad, Alan H., W. Michael Hanemann, and Maximilian Auffhammer. 2006. "End-Use Energy Efficiency in a 'post- Carbon' California Economy." In Managing Greenhouse Gas Emissions in California, edited by W. Michael Hanemann and Alexander E. Farrell. Berkeley, CA: The California Climate Change Center at UC Berkeley.

Schleich, Joachim. 2009. "Barriers to Energy Efficiency: A Comparison across the German Commercial and Services Sector." Ecological Economics 68 (7): 2150-59. http://dx.doi. org/10.1016/j.ecolecon.2009.02.008.

Sebold, Frederick, and Eric Fox. 1985. "Realized Savings from Residential Conservation Activity." The Energy Journal 6 (2): 73-88. http://dx.doi.org/10.5547/ISSN0195-6574-EJ-Vol6No2-6.

Sharma, Dhruv N. 2011. "Economic Efficiency and Distributional Impacts of Policies for Increasing U.S. Residential Insulation.” Ph.D., Stanford University. http://search.proquest.com.ezpprod1.hul.harvard.edu/docview/907105902/abstract?accountid=11311.

Sorrell, Steve, Eoin O’Malley, Joachim Schleich, and Sue Scott. 2004. "Standing on a Burning Platform: Barriers to Energy Efficiency in the UK Brewing Industry." In The Economics of Energy Effciency: Barriers to Cost-Effective Investment, 349. Cheltenham: Edward Elgar.

Ternes, Mark P., and Michael B. Gettings. 2008. Analyses to Verify and Improve the Accuracy of the Manufactured Home Energy Audit (MHEA). Oak Ridge National Laboratory (ORNL). http:// weatherization.ornl.gov/pdfs/ORNL_CON-506.pdf.

Thollander, Patrik, Maria Danestig, and Patrik Rohdin. 2007. "Energy Policies for Increased Industrial Energy Efficiency: Evaluation of a Local Energy Programme for Manufacturing SMEs.” Energy Policy 35 (11): 5774-83. http://dx.doi.org/10.1016/j.enpol.2007.06.013.

Thollander, Patrik, and Mikael Ottosson. 2008. "An Energy Efficient Swedish Pulp and Paper Industry - Exploring Barriers to and Driving Forces for Cost-Effective Energy Efficiency Investments.” Energy Efficiency 1 (1): 21-34. http://dx.doi.org/10.1007/s12053-007-9001-7. 
Tietenberg, Tom. 2009. "Reflections-Energy Efficiency Policy: Pipe Dream or Pipeline to the Future." Review of Environmental Economics and Policy 3 (2): 304-20. http://dx.doi. org/10.1093/reep/rep004.

Tonn, Bruce, and Linda G. Berry. 1986. "Determinants of Participation in Home Energy Audit/ Loan Programs: Discrete Choice Model Results.” Energy 11 (8): 785-95. http://dx.doi. org/10.1016/0360-5442(86)90017-4.

Trianni, A., and E. Cagno. 2012. "Dealing with Barriers to Energy Efficiency and SMEs: Some Empirical Evidences.” Energy 37 (1): 494-504. http://dx.doi.org/10.1016/j. energy.2011.11.005.

Turrentine, Thomas S., and Kenneth S. Kurani. 2007. "Car Buyers and Fuel Economy?” Energy Policy 35 (2): 1213-23. http://dx.doi.org/10.1016/j.enpol.2006.03.005.

U.K. Department of Energy and Climate Change. 2013. Removing the Hassle Factor Associated with Loft Insulation: Results of a Behavioural Trial. London. https://www.gov.uk/government/ uploads/system/uploads/attachment_data/file/236858/DECC_loft_clearance_trial_report_ final.pdf.

Ungemach, C, Adrian R. Camilleri, E.J. Johnson, Richard P. Larrick, and Elke U. Weber. 2014. "Translated Attributes as a Choice Architecture Tool: Trick and Treat." Summary of Working Paper. http://adriancamilleri.net/wp-content/uploads/Camilleri-et-al.-2013.-JPPM-extendedabstract.pdf?770196.

U.S. Environmental Protection Agency. 2014. "Learn About the New Label.” www.fueleconomy.gov/ feg/label/.

Verboven, Frank. 2002. "Quality-Based Price Discrimination and Tax Incidence: Evidence from Gasoline and Diesel Cars.” The RAND Journal of Economics 33 (2): 275-97. www.jstor.org/ stable/3087434.

Walls, Margaret, Karen L. Palmer, and Todd Gerarden. 2013. Is Energy Efficiency Capitalized into Home Prices? Evidence from Three US Cities. Discussion Paper 13-18. Washington, D. C.: Resources for the Future. www.rff.org/Publications/Pages/PublicationDetails. aspx?PublicationID=22230. 
Zivin, Joshua Graff, Matthew Kotchen, and Erin T. Mansur. 2012. Spatial and Temporal Heterogeneity of Marginal Emissions: Implications for Electric Cars and Other Electricity-Shifting Policies. Working Paper 18462. National Bureau of Economic Research. www.nber.org/papers/ w18462. 